purposes of being able to demonstrate an effect of the treatment in this particular trial, studying a disease which has a high spontaneous remission rate. Most parents, however, would wish their child to be treated at a much lower level of risk. The threshold for treatment ought to be set at that level at which the benefits from treatment outweigh its risks. We have learned much about the natural history of ROP - a very unpredictable disease - but we know little of the risks to the infant from treatment. What are the risks from anaesthesia? What are the adverse effects on the eye from the peripheral retinal ablation? We know that laser has fewer of these than cryotherapy but still know little about the long-term consequences on the patients' visual acuities and fields. The treatment threshold for ROP probably has been set too high; further studies on the outcomes of treatment are needed to discover at what level it ought to be set.

Queen's Medical Centre

Nottingham

\section{References}

1. Escobar GJ, Littenberg B, Petitti DB. Outcome among surviving very low birthweight infants: a meta-analysis. Arch Dis Child 1991;66:204.

2. McKibbin M, Dabbs TR. Assisted conception and retinopathy of prematurity. Eye 1996;10:411-530.

3. Pennefather $\mathrm{P}$, et al. Refractive errors in children born before 32 weeks gestation. Eye 1997;11:736-43.

4. Cryotherapy for Retinopathy of Prematurity Cooperative Group. Multicentre trial of cryotherapy for retinopathy of prematurity: preliminary results. Arch Opthalmol 1988;106:471-9.

5. Algawi K, Goggin M, O'Keefe M. Refractive outcome following diode laser versus cryotherapy for eyes with retinopathy of prematurity. Br J Ophthalmol 1994;78: $612-4$.

6. White JE, Repka MX. Randomised comparison of diode laser photocoagulation versus cryotherapy for threshold retinopathy of prematurity: a 3-year outcome. J Paediatr Ophthalmol Strabismus 1997;34:83-7.

7. Taddio A, Katz J, Ilersich AL, Koren G. Effect of neonatal circumcision on pain response during subsequent routine vaccination. Lancet 1997;349:599-603.

\title{
AN OUNCE OF PREVENTION IS WORTH A POUND OF CURE?
}

The fascinating paper by Claridge and her colleagues in this issue ${ }^{1}$ on the medical suppression of active dysthyroid eye disease should cause all of us who see such patients to reassess our approach to them.

The study concerns 40 consecutive patients with active thyroid eye disease who were treated aggressively with immunosuppression, using primary orbital radiotherapy, azathioprine and corticosteroids. Patients had activity assessed with the Mourits and total eye scores before and after treatment, in addition to a full clinical examination including uniocular fields of fixation - a measure of absolute ocular motility, rather than a comparative technique such as a Hess chart.

Over an average period of 1.2 years, the eye disease became inactive, and treatment was well tolerated. One patient $(2.5 \%)$ required subsequent orbital decompression for cosmetic reasons, $6(15 \%)$ had strabismus surgery, and $13(32.5 \%)$ required minor lid surgery.

These are impressive figures, and are made even more so by the authors' contention that their treatment regime leads to a fourfold reduction in the requirement for subsequent orbital decompression and strabismus surgery. Regrettably, however, this figure is derived by comparison of their figures with those of Prummel et al. ${ }^{2}$ who may have applied an entirely different set of clinical criteria for their surgical interventions.
Also worthy of note in this context is the interesting series of papers by Bartley et $a l^{3-5}$ analysing an incidence cohort of 120 patients from Olmstead County, Minnesota, and derived from the computerised database at the Mayo Clinic. This cohort was collected over a period between 1976 and 1990, so management criteria might have changed. It is also evident that many patients had mild disease. However, 6 cases $(5 \%)$ received steroids for optic neuropathy, with 5 going on to orbital decompression, and 3 others $(2.5 \%)$ had primary orbital decompression. The strabismus surgery rate was $9.2 \%$, and the lid surgery rate $12.5 \%$. It is again unclear what criteria were applied for subsequent surgical intervention.

It seems unlikely that different groups of authors will be able to agree completely on the indications for surgery, in particular orbital decompression for reasons of cosmetic improvement and strabismus surgery for small deviations and head postures, and so until the treatment of cases of this most unpleasant and disabling disease can be analysed in a randomised controlled clinical trial, we will not know whether the use of immunosuppression to abort the ocular manifestations is as effective as Claridge and her colleagues clearly believe it to be. One hopes that such a trial will not be long overdue.

Moorfields Eye Hospital London
John Lee 


\section{References}

1. Claridge $\mathrm{K}$ et al. Combined radiotherapy and medical immunosuppression in the management of thyroid eye disease. Eye 1997;11:717-22.

2. Prummel MF, Mourits MP, Blank L, Berhout A, Koorneef L, Wiersinga WM. Randomised double-blind trial of prednisolone versus radiotherapy in Graves' ophthalmopathy. Lancet 1993;342:949-54.

3. Bartley GB, Fatourechi V, Kadrmas EF, Jacobsen SJ, Ilstrup DM, Garrity JA, Gorman CA. The incidence of
Graves' ophthalmopathy in Olmstead County, Minnesota. Am J Ophthalmol 1995;120:511-7.

4. Bartley GB, Fatourechi V, Kadrmas EF, Jacobsen SJ, Ilstrup DM, Garrity JA, Gorman CA. The treatment of Graves' ophthalmopathy in an incidence cohort. Am J Ophthalmol 1996;121:200-6.

5. Bartley GB, Fatourechi V, Kadrmas EF, Jacobsen SJ, Ilstrup DM, Garrity JA, Gorman CA. Clinical features of Graves' ophthalmopathy in an incidence cohort. Am J Ophthalmol 1996;121:284-90. 